\title{
Materials for Gas Turbines - An Overview
}

\author{
Nageswara Rao Muktinutalapati \\ VIT University \\ India
}

\section{Introduction}

Advancements made in the field of materials have contributed in a major way in building gas turbine engines with higher power ratings and efficiency levels. Improvements in design of the gas turbine engines over the years have importantly been due to development of materials with enhanced performance levels. Gas turbines have been widely utilized in aircraft engines as well as for land based applications importantly for power generation. Advancements in gas turbine materials have always played a prime role - higher the capability of the materials to withstand elevated temperature service, more the engine efficiency; materials with high elevated temperature strength to weight ratio help in weight reduction. A wide spectrum of high performance materials - special steels, titanium alloys and superalloys - is used for construction of gas turbines. Manufacture of these materials often involves advanced processing techniques. Other material groups like ceramics, composites and inter-metallics have been the focus of intense research and development; aim is to exploit the superior features of these materials for improving the performance of gas turbine engines.

The materials developed at the first instance for gas turbine engine applications had high temperature tensile strength as the prime requirement. This requirement quickly changed as operating temperatures rose. Stress rupture life and then creep properties became important. In the subsequent years of development, low cycle fatigue (LCF) life became another important parameter. Many of the components in the aero engines are subjected to fatigue- and / or creep-loading, and the choice of material is then based on the capability of the material to withstand such loads.

Coating technology has become an integral part of manufacture of gas turbine engine components operating at high temperatures, as this is the only way a combination of high level of mechanical properties and excellent resistance to oxidation / hot corrosion resistance could be achieved.

The review brings out a detailed analysis of the advanced materials and processes that have come to stay in the production of various components in gas turbine engines. While there are thousands of components that go into a gas turbine engine, the emphasis here has been on the main components, which are critical to the performance of the engine. The review also takes stock of the R\&D activity currently in progress to develop higher performance materials for gas turbine engine application. On design aspects of gas turbine engines, the reader is referred to the latest edition of the Gas Turbine Engineering Handbook (Boyce, 2006). 


\section{Compressor parts for aircraft engines - Titanium alloys}

Titanium, due to its high strength to weight ratio, has been a dominant material in compressor stages in aeroengines. Titanium content has increased from $3 \%$ in 1950s to about 33\% today of the aeroengine weight. Unlike predictions made for requirements of ceramic and metal matrix composites for aeroengines, predictions made for titanium alloys have come true or even surpassed. High temperature titanium alloys have found extensive application in aeroengines. Ti- $6 \mathrm{Al}-4 \mathrm{~V}$ is used for static and rotating components in gas turbine engines. Castings are used to manufacture the more complex static components. Forgings are typically used for the rotating components. For example, the alloy is used for fan disc and low pressure compressor discs and blades for the Pratt and Whitney 4084 engine. The alloy is used in the cooler compressor stages up to a maximum temperature of about $315{ }^{\circ} \mathrm{C}$. Ti-8Al-1Mo-1V is used for fan blades in military engines (Bayer, 1996). The alloys 685 (Ti-6Al-5Zr-0.5Mo-0.25Si) and 829 (Ti-5.5Al-3.5Sn-3Zr-1Nb-0.25Mo-0.3Si) are used in many current European aeroengines such as RB2111, 535E4 in fully beta heat treated condition to maximize creep resistance (Gogia, 2005). Alloy 834 (Ti-5.8Al-4Sn-3.5Zr-0.7Nb$0.5 \mathrm{Mo}-0.35 \mathrm{Si}-0.06 \mathrm{C})$, a relatively recent grade, in contrast is used in $\alpha+\beta$ condition, with a 5$15 \%$ equiaxed $\alpha$ in the microstructure to optimize both creep and fatigue strength (Gogia, 2005). The alloy was aimed at replacing the Alloys 685 and 829 preferred in European jet engines. Alloy 834 is used as a compressor disc material in the last two stages of the medium-pressure compressor, and the first four stages of the high pressure compressor in variants of the Rolls-Royce Trent series commercial jet engine. The Ti-1100 (Ti-6Al-2.8Sn$4 \mathrm{Zr}-0.4 \mathrm{Mo}-0.4 \mathrm{Si}$ ), a competitive alloy to IMI834, is designed to be used in the $\beta$ heat treated condition. The alloy is under evaluation by Allison Gas Turbine Engines for higher thrust versions of their 406/GMA3007/GMA2100 family of engines, primarily for castings (Gogia, 2005). The alloy has a claimed use temperature of 600 C. IN US, Ti6-2-4-2 (Ti-6Al-2Sn-4Zr$2 \mathrm{Mo}$ ) is the preferred high temperature alloy for jet engine applications. A variant of this alloy, Ti6-2-4-2S is also commercially available. The ' $S$ ' denotes addition of $0.1-0.25 \%$ Si to improve the creep resistance. It is used for rotating components such as blades, discs and rotors at temperatures up to about $540{ }^{\circ} \mathrm{C}$ (Bayer, 1996). It is used in high pressure compressors at temperatures too high for Ti-6-4, above about $315{ }^{\circ} \mathrm{C}$, for structural applications.

Today, the maximum temperature limit for near- $\alpha$ alloys for elevated temperature applications is about $540{ }^{\circ} \mathrm{C}$. This temperature limitation for titanium alloys mean the hottest parts in the compressor, i.e. the discs and blades of the last compressor stages, have to be manufactured from Ni-based superalloys at nearly twice the weight. Additionally, problems arise associated with the different thermal expansion behavior and the bonding techniques of the two alloy systems. Therefore enormous efforts are underway to develop a compressor made completely of titanium. Titanium alloys are required that can be used at temperatures of $600{ }^{\circ} \mathrm{C}$ or higher. This has been the impetus for extensive research and development work in the area of elevated temperature titanium alloys.

Table 1 gives the chemical composition and the maximum service temperature of various grades of titanium alloys mentioned above. Figure 1 shows schematically the relative creep capability of these grades in the form of a Larson Miller plot. The reader is referred to some excellent reviews on use of titanium alloys in gas turbine engines (Bayer, 1998; Gogia, 2005). The technical guide on titanium published by ASM International (Donachie, 2000) also gives much information on titanium as a gas turbine material. 


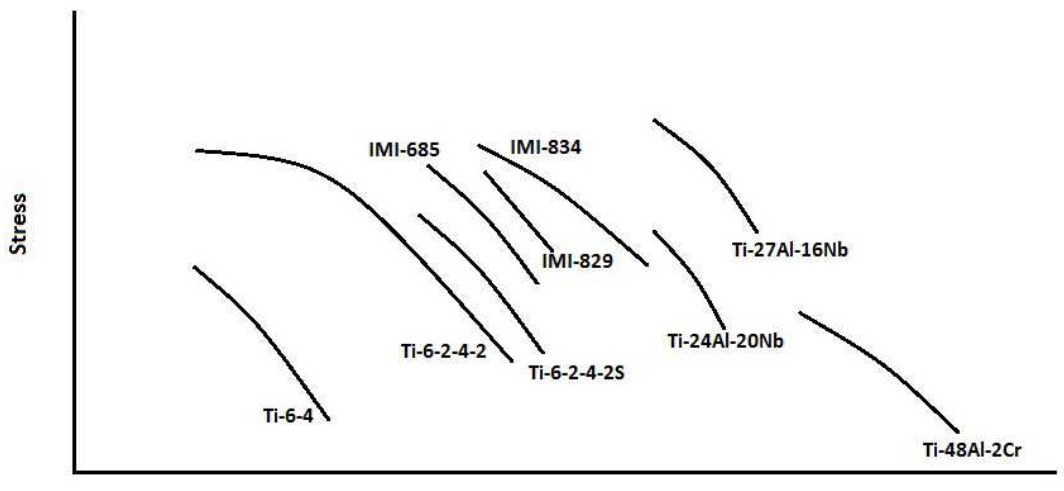

Larson Miller Parameter

Fig. 1. Relative creep capability of titanium alloys used for compressor parts in the form of a Larson Miller plot (Schematic).

\section{Compressor blading materials for land based gas turbines - Special steels}

Until recently, all production blades for compressors are made from $12 \%$ chromium containing martensitic stainless steel grades 403 or $403 \mathrm{Cb}$ (Schilke, 2004). Corrosion of compressor blades can occur due to moisture containing salts and acids collecting on the blading. To prevent the corrosion, GE has developed patented aluminum slurry coatings for the compressor blades. The coatings are also meant to impart improved erosion resistance to the blades. During the 1980's, GE introduced a new compressor blade material, GTD-450, a precipitation hardened martensitic stainless steel for its advanced and uprated machines (Schilke, 2004). Without sacrificing stress corrosion resistance, GTD-450 offers increased tensile strength, high cycle fatigue strength and corrosion fatigue strength, compared to type 403. GTD-450 also possesses superior resistance to acidic salt environments to type 403, due to higher concentration of chromium and presence of molybdenum (Schilke, 2004).

\begin{tabular}{|l|l|l|}
\hline $\begin{array}{l}\text { Grade } \\
\text { designation }\end{array}$ & Nominal chemical composition & $\begin{array}{l}\text { Maximum service } \\
\text { temperature }\left({ }^{\circ} \mathrm{C}\right)\end{array}$ \\
\hline Ti64 & Ti-6Al-4V & 315 \\
\hline Ti811 & Ti-8Al-1Mo-1V & 400 \\
\hline Alloy 685 & Ti-6Al-5Zr-0.5Mo-0.25Si & 520 \\
\hline Alloy 829 & Ti-5.5Al-3.5Sn-3Zr-1Nb-0.25Mo-0.3Si & 550 \\
\hline Alloy 834 & Ti-5.8Al-4Sn-3.5Zr-0.7Nb-0.5Mo-0.35Si-0.06C & 600 \\
\hline Ti1100 & Ti-6Al-2.8Sn-4Zr-0.4Mo-0.4Si & 600 \\
\hline Ti6242 & Ti-6Al-2Sn-4Zr-2Mo & \\
\hline Ti6242S & Ti-6Al-2Sn-4Zr-2Mo-0.2Si & 540 \\
\hline
\end{tabular}

Table 1. Titanium alloys used for compressor parts in aircraft engines - chemical composition and maximum service temperature 
Table 2 gives the chemical composition of the different steel grades used for compressor blading.

\begin{tabular}{|l|l|l|}
\hline Grade & Chemical composition & Remarks \\
\hline AISI 403 & Fe12Cr0.11C & Martensitic stainless steel \\
\hline AISI $403+\mathrm{Nb}$ & Fe12Cr0.2Cb0.15C & Martensitic stainless steel with Nb addition \\
\hline GTD-450 & Fe15.5Cr6.3Ni0.8Mo0.03C & Precipitation hardening stainless steel \\
\hline
\end{tabular}

Table 2. Compressor blade materials for land based gas turbines

\section{Combustion hardware for aircraft and industrial gas turbines (IGTs)}

Driven by the increased firing temperatures of the gas turbines and the need for improved emission control, significant development efforts have been made to advance the combustion hardware, by way of adopting sophisticated materials and processes.

The primary basis for the material changes that have been made is improvement of high temperature creep rupture strength without sacrificing the oxidation / corrosion resistance. Traditionally combustor components have been fabricated out of sheet nickel-base superalloys. Hastelloy X, a material with higher creep strength was used from 1960s to 1980s. Nimonic 263 was subsequently introduced and has still higher creep strength (Schilke, 2004). As firing temperatures further increased in the newer gas turbine models, HA-188, a cobalt base superalloy has been recently adopted for some combustion system components for improved creep rupture strength (Schilke, 2004). Coutsouradis et al. reviewed the applications of cobalt-base superalloys for combustor and other components in gas turbines (Coutsouradis et al., 1987). Nickel base superalloys 617 and 230 find wide application for combustor components (Wright \& Gibbons, 2007). Table 3 gives the chemical composition of combustor materials.

\begin{tabular}{|l|l|l|}
\hline Grade & Chemical composition & Remarks \\
\hline Hastelloy X & Ni22Cr1.5Co1.9Fe0.7W9Mo0.07C0.005B & Nickel-base superalloy \\
\hline Nimonic 263 & Ni20Cr20Co0.4Fe6Mo2.1Ti0.4Al0.06C & Nickel-base superalloy \\
\hline HA188 & Co22Cr22Ni1.5Fe14W0.05C0.01B & Cobalt-base superalloy \\
\hline 617 & 54Ni22Cr12.5Co8.5Mo1.2Al & Nickel-base superalloy \\
\hline 230 & 55Ni22Cr5Co3Fe14W2Mo0.35A10.10C0.015B & $\begin{array}{l}\text { Nickel-base superalloy; } \\
\text { values for Co, Fe and B } \\
\text { are upper limits. }\end{array}$ \\
\hline
\end{tabular}

Table 3. Combustor materials

In addition to designing with improved materials, combustion liners and transition pieces of advanced and uprated machines involving higher firing temperatures are given a thermal barrier coating (TBC). The coating serves to provide an insulating layer and reduces the underlying base metal temperature. Section 9 deals with the subject of TBC in detail.

\section{Turbine disk applications}

\subsection{Aircraft engines - Superalloys}

A286, an austenitic iron-base alloy has been used for years in aircraft engine applications (Schilke, 2004). Superalloy 718 has been used for manufacture of discs in aircraft engines for 
more than 25 years (Schilke, 2004). Both these alloys have been produced through the conventional ingot metallurgy route.

Powder Metallurgy (PM) processing is being extensively used in production of superalloy components for gas turbines. PM processing is essentially used for Nickel-based superalloys. It is primarily used for production of high strength alloys used for disc manufacture such as IN100 or Rene95 which are difficult or impractical to forge by conventional methods. LC Astroloy, MERL 76, IN100, Rene95 and Rene88 DT are the PM superalloys where ingot metallurgy route for manufacture of turbine discs was replaced by the PM route.

The advantages of PM processing are listed in the following:

- Superalloys such as IN-100 or Rene95 difficult or impractical to forge by conventional methods. $\mathrm{P} / \mathrm{M}$ processing provides a solution

- Improves homogeneity / minimizes segregation, particularly in complex Ni-base alloy systems

- Allows closer control of microstructure and better property uniformity within a part than what is possible in cast and ingot metallurgy wrought products. Finer grain size can be realized.

- Alloy development flexibility due to elimination of macro-segregation.

- Consolidated powder products are often super-plastic and amenable to isothermal forging, reducing force requirements for forging.

- It is a near net shape process; hence significantly less raw material input required and also reduced machining cost, than in case of conventional ingot metallurgy.

Several engines manufactured by General Electric and Pratt and Whitney are using superalloy discs manufactured through PM route.

Table 4 gives the details of disc superalloys for aircraft engines.

\begin{tabular}{|c|c|c|}
\hline Grade & Chemical composition & Remarks \\
\hline A286 & $\begin{array}{l}\text { Fe15Cr25Ni1.2Mo2Ti0.3Al0.25V } \\
0.08 \mathrm{C} 0.006 \mathrm{~B}\end{array}$ & $\begin{array}{l}\text { Iron-base superalloy; ingot } \\
\text { metallurgy route }\end{array}$ \\
\hline 718 & Ni19Cr18.5Fe3Mo0.9Ti0.5Al5.1Cb 0.03C & $\begin{array}{l}\text { Nickel-iron-base superalloy; } \\
\text { ingot metallurgy route }\end{array}$ \\
\hline IN 100 & $\begin{array}{l}\text { 60Ni10Cr15Co3Mo4.7Ti5.5Al0.15C 0.015B } \\
\text { 0.06Zr1.0V }\end{array}$ & $\begin{array}{l}\text { Nickel-base superalloy; } \\
\text { powder metallurgy route }\end{array}$ \\
\hline Rene 95 & $\begin{array}{l}\text { 61Ni14Cr8Co3.5Mo3.5W3.5Nb2.5Ti3.5Al } \\
\text { 0.16C0.01B0.05Zr }\end{array}$ & $\begin{array}{l}\text { Nickel-base superalloy; } \\
\text { powder metallurgy route }\end{array}$ \\
\hline LC Astroloy & $\begin{array}{l}\text { 56.5Ni15Cr 15Co5.25Mo3.5Ti4.4Al } \\
0.06 \mathrm{C} 0.03 \mathrm{~B} 0.06 \mathrm{Zr}\end{array}$ & $\begin{array}{l}\text { Nickel-base superalloy; } \\
\text { powder metallurgy route }\end{array}$ \\
\hline MERL-76 & $\begin{array}{l}\text { 54.4Ni12.4Cr18.6co3.3Mo1.4Nb } \\
\text { 4.3Ti5.1Al0.02C0.03B0.35Hf0.06Zr }\end{array}$ & $\begin{array}{l}\text { Nickel-base superalloy; } \\
\text { powder metallurgy route }\end{array}$ \\
\hline Rene88 DT & $\begin{array}{l}\text { 56.4Ni16cr13Co4Mo4W0.7Nb3.7Ti } \\
\text { 2.1A10.03C0.015B0.03Zr }\end{array}$ & $\begin{array}{l}\text { Nickel-base superalloy; } \\
\text { powder metallurgy route }\end{array}$ \\
\hline Udimet 720 & $\begin{array}{l}\text { 55Ni18Cr14.8Co3Mo1.25W5Ti2.5Al0.035C } \\
0.033 \mathrm{~B} 0.03 \mathrm{Zr}\end{array}$ & $\begin{array}{l}\text { Nickel-base superalloy; } \\
\text { ingot metallurgy / powder } \\
\text { metallurgy route }\end{array}$ \\
\hline $\begin{array}{l}\text { Udimet } \\
\text { 720LI }\end{array}$ & $\begin{array}{l}\text { 57Ni16Cr15Co3Mo1.25W5Ti2.5Al0.025C0. } \\
\text { 018B0.03Zr }\end{array}$ & $\begin{array}{l}\text { Low C, low B variant of } \\
\text { Udimet } 720 .\end{array}$ \\
\hline
\end{tabular}

Table 4. Disc superalloys for aircraft engines 


\subsection{IGTs - Steels and superalloys}

Turbine discs of most GE single shaft heavy duty gas turbines are made of $1 \% \mathrm{Cr}-1.25 \% \mathrm{Mo}-$ $0.25 \% \mathrm{~V}$ steel in hardened and tempered condition (Schilke, 2004). 12\% Cr steels such as M152 have higher rupture strength than $\mathrm{Cr}-\mathrm{Mo}-\mathrm{V}$ steel, in addition to outstanding fracture toughness and capacity to attain uniform and high mechanical properties in large sections. Use of A286 for IGTs started in 1965, when the technological advancements made it possible to produce large ingots of this material with required quality (Schilke, 2004).

With the advent of advanced of gas turbine engines with much higher firing temperatures and compressor ratios, it became necessary to utilize a nickel-base superalloy, alloy 706 for the rotors. The use of this material provides the necessary temperature capability required to also meet the firing temperature requirements in the future. This alloy is similar to the Alloy 718, an alloy that has been used for rotors in aircraft engines for more than 25 years. Alloy 706 contains lower concentrations of alloying elements known for their tendency to segregate. Consequently it is less segregation-prone than Alloy 718 and could be produced in large diameters unlike Alloy 718. Accordingly large sized rotors of Alloy 706 could be produced to serve large IGTs for land-based power generation (Schilke, 2004). Alloy 718, the most frequently used superalloy for aircraft gas turbines, because of its segregation tendency, could be produced, until the turn of the century, to a maximum ingot size of $500 \mathrm{~mm}$. Developments made with reference to remelting techniques, together with very close control on chemical composition have enabled production of ingots of Alloy 718 as large as $750 \mathrm{~mm}$ in diameter. This has resulted in the ability to process Alloy 718 to the large disk sizes needed in modern IGTs.

The importance of Alloy 718 and Alloy 706 can be seen from the fact that several international conferences have been devoted to developments related to these alloys (Loria, 1989, 1991, 1994, 1997, 2001, 2005; Caron et al., 2008).

\begin{tabular}{|c|c|c|}
\hline Grade & Chemical composition & Remarks \\
\hline $\begin{array}{l}\text { CrMoV } \\
\text { steel }\end{array}$ & Fe1Cr0.5Ni1.25Mo0.25V0.30C & $\begin{array}{l}\text { Medium carbon } \\
\text { low alloy steel }\end{array}$ \\
\hline M152 & Fe12Cr2.5Ni1.7Mo0.3V0.12C & $12 \%$ Cr steel \\
\hline A286 & $\begin{array}{l}\text { Fe15Cr25Ni1.2Mo2Ti0.3Al0.25V } \\
0.08 \mathrm{C} 0.006 \mathrm{~B}\end{array}$ & $\begin{array}{l}\text { Iron-base } \\
\text { superalloy }\end{array}$ \\
\hline 706 & Ni16Cr37Fe1.8Ti2.9Cb0.03C & $\begin{array}{l}\text { Nickel-iron-base } \\
\text { superalloy }\end{array}$ \\
\hline 718 & Ni19Cr18.5Fe3Mo0.9Ti0.5Al5.1Cb 0.03C & $\begin{array}{l}\text { Nickel-iron-base } \\
\text { superalloy }\end{array}$ \\
\hline $\begin{array}{l}\text { Udimet } \\
720\end{array}$ & 55Ni18Cr14.8Co3Mo1.25W5Ti2.5A10.035C0.033B0.03Zr & $\begin{array}{l}\text { Nickel-base } \\
\text { superalloy }\end{array}$ \\
\hline $\begin{array}{l}\text { Udimet } \\
\text { 720LI }\end{array}$ & 57Ni16Cr15Co3Mo1.25W5Ti2.5Al0.025C0.018B0.03Zr & $\begin{array}{l}\text { Nickel-base } \\
\text { superalloy }\end{array}$ \\
\hline
\end{tabular}

Table 5. Disc materials for IGTs

Udimet 720 also evolved as an advanced wrought alloy for land based gas turbines. Reductions in $\mathrm{Cr}$ content to prevent sigma phase formation and in carbon and boron levels 
to reduce stringers and clusters of carbides, borides or carbonitrides have led to the development of the Alloy 720LI. Both these alloys have been of considerable interest to land based gas turbines. They have also been incorporated in some aircraft gas turbines (Furrer \& Fecht, 1999). Table 5 gives details of special steels / superalloys used for production of discs for land-based gas turbines.

The reader is referred to an overview by Furrer and Fecht on nickel-based superalloys for turbine discs for land based power generation and aircraft propulsion (Furrer \& Fecht, 1999).

\section{Turbine blades and vanes - Cast superalloys}

Recognition of the material creep strength as an important consideration for the gas turbine engines, understanding generated between age hardening, creep and $\gamma^{\prime}$ volume fraction and the steadily increasing operating-temperature requirements for the aircraft engines resulted in development of wrought alloys with increasing levels of aluminum plus titanium. Component forgeability problems led to this direction of development not going beyond a certain extent. The composition of the wrought alloys became restricted by the hot workability requirements. This situation led to the development of cast nickel-base alloys. Casting compositions can be tailored for good high temperature strength as there was no forgeability requirement. Further the cast components are intrinsically stronger than forgings at high temperatures, due to the coarse grain size of castings. Das recently reviewed the advances made in nickel-based cast superalloys (Das, 2010).

Buckets (rotating airfoils) must withstand severe combination of temperature, stress and environment. The stage 1 bucket is particularly loaded, and is generally the limiting component of the gas turbine. Function of the nozzles (stationary airfoils) is to direct the hot gases towards the buckets. Therefore they must be able to withstand high temperatures. However they are subjected to lower mechanical stresses than the buckets. An important design requirement for the nozzle materials is that they should possess excellent high temperature oxidation and corrosion resistance.

\subsection{Conventional equiaxed investment casting process \\ 6.1.1 Aircraft engines}

Cast alloy IN-713 was among the early grades established as the materials for the airfoils in the most demanding gas turbine application. Efforts to increase the $\gamma^{\prime}$ volume fraction to realize higher creep strength led to the availability of alloys like IN 100 and Rene 100 for airfoils in gas turbine engines. Increased amount of refractory solid solution strengtheners such as $\mathrm{W}$ and Mo were added to some of the grades developed later and this led to the availability of grades like MAR-M200, MAR-M246, IN 792 and M22. Addition of 2 wt\% Hf improved ductility and a new series of alloys became available with Hf addition such as MAR-M200+Hf, MAR-M246+Hf, Rene 125+Hf.

General Electric pursued own alloy development with Rene 41, Rene 77, Rene 80 and Rene $80+$ Hf having relatively high chromium content for improved corrosion resistance at the cost of some high temperature strength. Other similar alloys with high chromium content are IN738C, IN738LC, Udimet 700, Udimet 710.

Table 6 gives details of superalloy compositions of airfoils produced by conventional equiaxed investment casting process. 


\begin{tabular}{|l|l|}
\hline Grade designation & Chemical composition \\
\hline IN 713 & 74.2Ni12.5Cr4.2Mo2Nb0.8Ti6.1Al0.1Zr0.12C0.01B \\
\hline IN 100 & 60.5Ni10Cr15Co3Mo4.7Ti5.5A10.06Zr0.18C0.014B \\
\hline Rene 100 & 62.6Ni9.5Cr15Co3Mo4.2Ti5.5A10.06Zr0.15C0.015B \\
\hline MAR-M200 & 59.5Ni9Cr10Co12.5W1.8Nb2Ti5A10.05Zr0.15C0.015B \\
\hline MAR-M246 & 59.8Ni9Cr10Co2.5Mo10W1.5Ta1.5Ti5.5A10.05Zr0.14C0.015B \\
\hline IN 792 & 60.8Ni12.7Cr9Co2Mo3.9W3.9Ta4.2Ti3.2A10.1Zr0.21C0.02B \\
\hline M 22 & 71.3Ni5.7Cr2Mo11W3Ta6.3A10.6Zr0.13C \\
\hline MAR-M200+Hf & Ni8Cr9Co12W2Hf1Nb1.9Ti5.0A10.03Zr0.13C0.015B \\
\hline MAR-M246+Hf & Ni9Cr10Co2.5Mo10W1.5Hf1.5Ta1.5Ti5.5A10.05Zr0.15C0.015B \\
\hline Rene 41 & 56Ni19Cr10.5Co9.5Mo3.2Ti1.7Al0.01Zr0.08C0.005B \\
\hline Rene 77 & 53.5Ni15Cr18.5Co5.2Mo3.5Ti4.25A10.08C0.015B \\
\hline Rene 80 & 60.3Ni14Cr9.5Co4Mo4W5Ti3al0.03Zr0.17C0.015B \\
\hline Rene 80+Hf & 59.8Ni14Cr9.5Co4Mo4W0.8Hf4.7Ti3A10.01Zr0.15C0.015B \\
\hline IN 738 & 61.5Ni16Cr8.5Co1.75Mo2.6W1.75Ta0.9Nb3.4Ti3.4A10.04Zr0.11C0.01B \\
\hline Udimet 700 & 59Ni14.3Cr14.5Co4.3Mo3.5Ti4.3A10.02Zr0.08C0.015B \\
\hline Udimet 710 & 59.8Ni3Cr12Co2Mo6W5Re6Ta0.1Hf6Al \\
\hline TMD-103 &
\end{tabular}

Table 6. Conventionally cast nickel-base superalloys for gas turbine blading applications in aircraft gas turbines

\subsubsection{Land-based gas turbine engines}

\subsubsection{Bucket materials for land based gas turbines}

Many of the GE engines used U-500 for stage 1 buckets in mid1960's. It is being used for later stages of buckets in selected gas turbine models (Schilke, 2004). IN738 has been used as stage 1 bucket material on several GE engines during 1971-1984. In recent years it has been also used as stage 2 bucket material in some GE engines (Schilke, 2004). The alloy has an outstanding combination of elevated temperature strength and hot corrosion resistance and this makes it attractive for heavy duty gas turbine applications. Developments in processing technology have enabled production of the alloy in large ingot sizes. The alloy is used throughout the heavy duty gas turbine industry. Subsequently GE has developed the alloy GTD-111, with higher strength levels than 738, but maintaining its hot corrosion resistance. GTD-111 has replaced IN738 as bucket material in different GE engine models (Schilke, 2004).

Table7 gives details of conventionally cast superalloys for blading applications in IGTs.

\begin{tabular}{|l|l|}
\hline Grade & Chemical composition \\
\hline Udimet 500 & Ni18.5Cr18.5Co4Mo3Ti3Al0.07C0.006B \\
\hline Rene 77 & Ni15Cr17Co5.3Mo3.35Ti4.25A10.07C0.02B \\
\hline IN738 & Ni16Cr8.3Co0.2Fe2.6W1.75Mo3.4Ti3.4A10.9Cb0.10C0.001B1.75Ta \\
\hline GTD 111 & Ni14Cr9.5Co3.8W1.5Mo4.9Ti3.0A10.10C0.01B2.8Ta \\
\hline
\end{tabular}

Table 7. Conventionally cast nickel-base superalloys for blading applications in IGTs 


\subsubsection{Nozzle materials for land based gas turbines}

GE engines use FSX 414, a GE-patented cobalt base alloy for all stage 1 nozzles and some later stage nozzles. Cobalt base alloys possess superior strength at very high temperatures compared to nickel base superalloys - hence the choice of cobalt base superalloy. It has a two-three fold oxidation resistance compared to $\mathrm{X} 40$ and $\mathrm{X} 45$, also cobalt based superalloys used for nozzle applications. Use of FSX 414 over C40/C45 hence enables increased firing temperatures for a given oxidation life (Schilke, 2004).

Later stage nozzles must also possess adequate creep strength and GE developed a nickel base superalloy GTD222 for some stage 2 and stage 3 applications. The alloy has significantly higher creep strength compared to FSX414. N155, an iron-based superalloy, has good weldability and is used for later stage nozzles of some GE engines (Schilke, 2004). Table 8 gives the details of materials used for nozzles in IGTs.

\begin{tabular}{|l|l|l|}
\hline Grade & Chemical composition & Remarks \\
\hline X40 & Co-25Cr10Ni8W1Fe0.5C0.01B & Cobalt-base superalloy \\
\hline X45 & Co-25Cr10Ni8W1Fe0.25C0.01B & Cobalt-base superalloy \\
\hline FSX414 & Co-28Cr10Ni7W1Fe0.25C0.01B & Cobalt-base superalloy \\
\hline N155 & Fe-21Cr20Ni20Co2.5W3Mo0.20C & Iron-base superalloy \\
\hline GTD-222 & Ni-22.5Cr19Co2.0W2.3Mo1.2Ti0.8A10.10V 0.008C1.0B & Nickel-base superalloy \\
\hline
\end{tabular}

Table 8. Nozzle materials for IGTs

\subsection{Directionally solidified (DS) castings}

\subsubsection{Aircraft engines}

The major failure mechanism for gas turbine airfoils involved nucleation and growth of cavities along transverse grain boundaries. Elimination of transverse grain boundaries through directional solidification of turbine blades and vanes made an important step in temperature capability of these castings. Use of DS superalloys could improve the turbine blade metal temperature capability by about $14{ }^{\circ} \mathrm{C}$ relative to the conventionally cast superalloys.

\begin{tabular}{|l|l|l|}
\hline $\begin{array}{l}\text { Grade } \\
\text { designation }\end{array}$ & Chemical composition & Remarks \\
\hline $\begin{array}{l}\text { DS MAR } \\
\text { M-200+Hf }\end{array}$ & $59.5 \mathrm{Ni}$ Cr10Co12.5W2Hf1.8Nb2Ti5A10.05Zr0.15C0.015B & $\begin{array}{l}\text { First } \\
\text { generation }\end{array}$ \\
\hline CM247LC & $61.7 \mathrm{Ni} 8.1 \mathrm{Cr} 9.2 \mathrm{Co} 0.5 \mathrm{Mo} 9.5 \mathrm{~W} 3.2 \mathrm{Ta} 1.4 \mathrm{Hf} 0.7 \mathrm{Ti5} .6 \mathrm{Al} 0.01 \mathrm{Z} 0.07 \mathrm{C} 0.015 \mathrm{~B}$ & $\begin{array}{l}\text { First } \\
\text { generation }\end{array}$ \\
\hline PWA1422 & $59.2 \mathrm{Ni}$ Cr10Co12W1.5Hf1Nb2Ti5Al0.1Zr0.14C0.015B & $\begin{array}{l}\text { First } \\
\text { generation }\end{array}$ \\
\hline DMD4 & 66.8Ni2.4Cr4Co5.5W6.5Re8Ta1.2Hf0.3Nb5.2A10.07C0.01B & $\begin{array}{l}\text { Third } \\
\text { generation }\end{array}$ \\
\hline
\end{tabular}

Table 9. DS nickel-base superalloys for blading applications in aircraft engines 
By early 1980s, DS superalloys became available and were operating in gas turbines. DS MAR-M-200+Hf became available. Another DS grade CM247LC is the outcome of extensive efforts to optimize the chemical composition to improve carbide microstructure, grain boundary cracking resistance, to minimize the formation of deleterious secondary phases and to avoid $\mathrm{HfO}_{2}$ inclusion problem. Pratt and Whitney developed an equivalent DS grade PWA 1422.

Table 9 gives details of DS superalloy compositions for aircraft engines.

\subsubsection{Land-based gas turbine engines}

GE has been using the DS version of DTD-111 for stage 1 buckets of different engines. It is same as DTD-111 equiaxed, except tighter control on alloy chemistry. DS version of DTD111 is stated to possess improved creep life, improved fatigue life and higher impact strength, compared to equiaxed version (Schilke, 2004). Use of DS superalloys could improve the turbine blade metal temperature capability by about $14{ }^{\circ} \mathrm{C}$ relative to the conventionally cast superalloys. TMD-103 belongs to the recent advances in DS alloy castings for IGT airfoil castings. It has very attractive long term creep rupture strength and hot corrosion resistance. The alloy could be directionally solidified in the form of large hollow blades for 2000KW IGT. Alloy chemistry of IGT buckets/vanes differs greatly from that of aeroengine blade/vane alloys, both on account of different operating scenarios and DS processing difficulties due to the large size of IGT components. Table 10 gives details of DS superalloy compositions for airfoils in IGTs.

\subsection{Single crystals}

In single crystal (SC) castings all grain boundaries are eliminated from the microstructure and an SC with a controlled orientation is produced in an airfoil shape. SCs required no grain boundary strengtheners such as C, B, Zr and Hf. Elimination of these elements while designing the SC compositions helped in raising the melting temperature and correspondingly the high temperature strength. Figure 2 schematically shows the improvement in creep strength of a cast superalloy by switching over from equiaxed polycrystalline investment casting to DS casting to SC casting.

\begin{tabular}{|l|l|l|}
\hline $\begin{array}{l}\text { Grade } \\
\text { designation }\end{array}$ & Chemical composition & Remarks \\
\hline DTD 111 & $\begin{array}{l}\text { Same as DTD 111 for equiaxed version, but with tighter } \\
\text { control on alloy chemistry }\end{array}$ & $\begin{array}{l}\text { Third } \\
\text { generation } \\
\text { superalloy }\end{array}$ \\
\hline TMD-103 & 59.8Ni3Cr12Co2Mo6W5Re6Ta0.1Hf6Al0.07C0.015B \\
\hline
\end{tabular}

Table 10. DS nickel-base superalloys for application as rotating blades in IGTs

\subsubsection{Aircraft engines}

The early SC superalloys included RR2000, RR2060 of Rolls Royce, PWA1480 of Pratt and Whitney, CMSX2 and CMSX3 of Cannon Muskegon and ReneN4 of GE. These SC alloys provided about $20^{\circ} \mathrm{C}$ metal temperature advantage over the existing DS alloys.

Attempts to further improve the metal temperature capability of SC superalloys by way of increasing the refractory alloying elements, prominently Rhenium, led to the development 
of SC superalloy grades PWA 1484, CMSX4, Rene N5, TUT92. These grades gave about 30 oC metal temperature improvement over the early SC superalloys.

Development of SC superalloys continued with the target of achieving another $30{ }^{\circ} \mathrm{C}$ improvement in metal temperature capability while maintaining the environmental resistance and freedom from appearance of deleterious phases in the microstructure. This led to emergence of grades CMSX10, Rene-6, TMS75, TMS80, MC-NG developed by Onera in France, DMS4 developed by DMRL, India, TMS-196, developed by NIMS, Japan. Detailed studies / evaluation have been carried out on these grades and they are potential candidate alloys for future gas turbine engines with enhanced performance.

Figure 3 schematically shows the improvement in stress rupture strength of superalloys, by moving over from DS (CM247) to first generation SC (CMSX2) to second generation SC (CMSX4) to third to fifth generation (CMSX10 and TMS 196) SCs, in the form of a Larson Miller plot.

Table 11 gives details of the superalloys used for blading applications in aircraft engines.

\subsubsection{Land-based gas turbines}

Development of SC castings has also benefited to improve the efficiency of combined cycle power plants by way of increasing the engine firing temperatures. GE has been applying the SC bucket technology for last several years. SC alloys such as CMSX11B, AF56, PWA1483 containing about $12 \% \mathrm{Cr}$ for long term environmental resistance together with additions of C, B, Hf to enhance alloy tolerance to low angle boundaries have been developed as airfoil materials. SC alloys such as CMSX 11C and SC 16 have been developed with $\mathrm{Cr}>12 \%$ to increase resistance to hot corrosion and oxidation. Long term phase stability was an important consideration in design of these alloys. Gibbons reviewed the improvements that are taking place with reference to alloys and coatings for integrated gasification combined cycle systems (IGCC) (Gibbons, 2009)

Table 12 gives details of SC superalloys used for rotating blade application in IGTs.

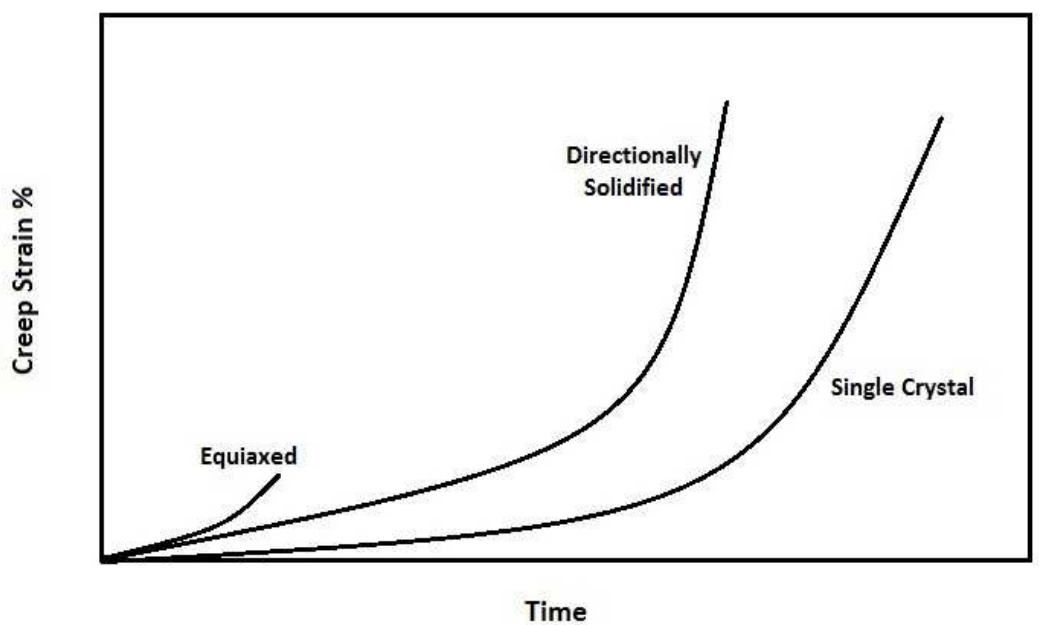

Fig. 2. Relative creep deformation of equiaxed, DS and SC superalloy castings (schematic) 


\section{Vanes - Oxide Dispersion Strengthened (ODS) superalloys}

A limited use exists for ODS superalloys in gas turbine engines. ODS superalloys are advanced high temperature materials which can retain useful strength up to a relatively high fraction of their melting point. This advantage is due to the uniformly dispersed, stable oxide particles which act as barriers to dislocation motion. MA754 has been in production by General Electric as a vane material since 1980. Because of its high long time elevated temperature strength, it has been extensively used for aircraft gas turbine vanes.

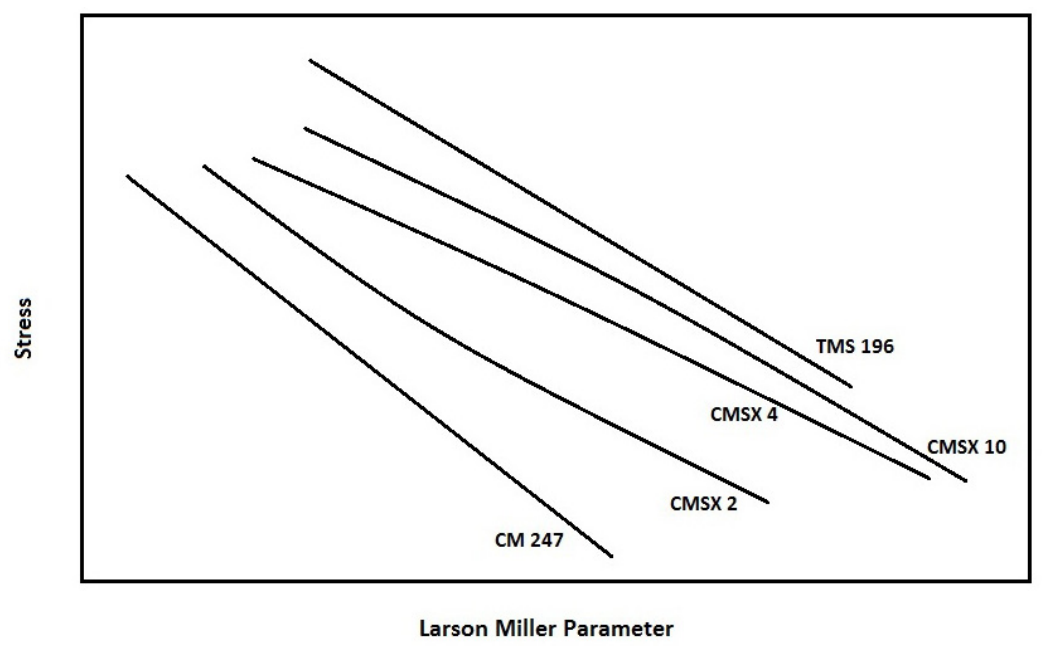

Fig. 3. Improvements made in the stress rupture strength of superalloys through advancements in processing technology (Schematic)

The modern high-performance gas turbine engines would not have been there but for the major advances made in superalloy development over the past 50 years, as outlined above. Excellent monographs / handbooks / technical guides are available on the subject of superalloys, covering different aspects - metallurgy, processing, properties and applications (Davis, 1997; Davis, 2000; DeHaemer, 1990; Donachie \& Donachie, 2002; Durand-Charre, 1998; Reed, 2006). The reader is referred to them for more detailed information.

\section{Reaction with the operating environment}

During operation the turbine components are subjected to environmentally induced degradation. The reaction with the environment is essentially of two types - hot corrosion and high temperature oxidation.

Hot corrosion is a rapid form of attack generally associated with alkali metal contaminants sodium and potassium - reacting with sulfur in the fuel to form molten sulfates. Two distinct forms of hot corrosion have been identified - high temperature hot corrosion occurring in the temperature range 850-950 ${ }^{\circ} \mathrm{C}$ and low temperature hot corrosion taking place in the range 593-760 ${ }^{\circ} \mathrm{C}$. Macroscopic and microscopic characteristics and mechanisms of the two forms of hot corrosion in gas turbine components have been reviewed (Eliaz et 


\begin{tabular}{|c|c|c|c|}
\hline Generation & $\begin{array}{l}\text { Grade } \\
\text { designation }\end{array}$ & Chemical composition & $\begin{array}{l}\text { Metal } \\
\text { temperature } \\
\text { capability oC }\end{array}$ \\
\hline \multirow[t]{6}{*}{ First } & RR2000 & 62.5Ni10Cr15Co3Mo4Ti5.5Al1V & \\
\hline & RR2060 & 63Ni15Cr5Co2Mo2W5Ta2Ti5Al & \\
\hline & PW1480 & 62.5Ni10Cr5Co4W12Ta1.5Ti5Al & 1060 \\
\hline & CMSX2 & 66.2Ni8Cr4.6Co0.6Mo8W6Ta1Ti5.6Al & \\
\hline & CMSX3 & 66.1Ni8Cr4.6Co0.6Mo8W6Ta0.1Hf1Ti5.6Al & \\
\hline & Rene N4 & 62Ni9.8Cr7.5Co1.5Mo6W4.8Ta0.15Hf0.5Nb3.5Ti4.2Al & \\
\hline \multirow[t]{4}{*}{ Second } & PWA1484 & 59.4Ni5Cr10Co2Mo6W3Re9Ta5.6Al & 1120 \\
\hline & CMSX4 & 61.7Ni6.5Cr9Co0.6Mo6W3Re6.5Ta0.1Hf1Ti5.6Al & \\
\hline & Rene N5 & 63.1Ni7Cr7.5Co1.5Mo5W3Re6.5Ta0.15Hf6.2Al0.05C0.004b0.01Y & \\
\hline & TUT 92 & 68Ni10Cr1.2Mo7W0.8Re8Ta1.2Ti5.3Al & \\
\hline \multirow[t]{7}{*}{$\begin{array}{l}\text { Third to } \\
\text { fifth }\end{array}$} & CMSX10 & 69.6Ni2Cr3Co0.4Mo5W6Re8Ta0.03Hf0.1Nb0.2Ti5.7Al & 1135 \\
\hline & ReneN6 & 57.3Ni4.2Cr12.5Co1.4Mo6W5.4R e7.2Ta0.15Hf5.8A10.05C0.004B & 1110 \\
\hline & TMS 75 & 59.9Ni3Cr12Co2Mo6W5Re6Ta0.1Hf6Al & 1115 \\
\hline & TMS 80 & 58.2Ni2.9Cr11.6Co1.9Mo5.8W4.9Re5.8Ta0.1Hf5.8Al0.5B3.0Ir & \\
\hline & MC-NG & 70.3Ni4Cr<0.2Co1Mo5W4Re5Ta0.1Hf0.5Ti6Al4.0Ru & \\
\hline & DMS4 & 67Ni2.4Cr4Co5.5W6.5Re9Ta0.1Hf0.3Nb5.2Al & 1140 \\
\hline & TMS 196 & 59.7Ni4.6Cr5.6Co2.4Mo5.0W6.4Re5.6Ta0.1Hf5.6Al5.0Ru & 1150 \\
\hline
\end{tabular}

Table 11. SC nickel-base superalloys for blading applications in aircraft engines

\begin{tabular}{|l|l|}
\hline Grade designation & Chemical composition \\
\hline CMSX11B & 62.1Ni12.5Cr7Co0.5Mo5W5Ta0.04Hf0.1Nb4.2Ti3.6Al \\
\hline AF56 & 61.4Ni12Cr3Mo5Ta4.2Ti3.4Al \\
\hline PWA1483 & 60.3Ni12.2Cr9Co1.9Mo3.8W5Ta0.5Hf4.1Ti3.6A10.07C0.008B \\
\hline CMSX11C & 64.5Ni14.9Cr3Co0.4Mo4.5W5Ta0.04Hf0.1Nb4.2Ti3.4Al \\
\hline SC16 & 70.5Ni16Cr3Mo3.5Ta3.5Ti3.5Al \\
\hline
\end{tabular}

Table 12. SC superalloys for advanced IGTs

al., 2002). When there is no presence of alkali metal contaminants and sulfur in the environment, high temperature oxidation dominates. Higher the temperature, more rapid is the oxidation. In this context, it is important to note the difference in the operating conditions of aircraft engines and heavy-duty gas turbines. Metal temperatures in the former are higher. The latter are subjected to excessive contamination through presence of 
sodium and sulfur in the operating environment and there is potential for extensive hot corrosion damage.

Alloying with elements which have a beneficial effect of cutting down the extent of hot corrosion has been adopted as an important approach to mitigate the problem. Similarly alloying with aluminum to enable the material form its own protective layer has been adopted to prevent high temperature oxidation. However these approaches do not take very far, as there are other functional requirements which also have to be taken care. Accordingly protective coatings have been developed to ward off the degradation. Most of the superalloys used for gas turbine components receive protection from specially engineered coatings.

\section{Coatings}

Having to perform under increasing firing temperatures and excessive contamination in the operating environment, it has become difficult to design superalloys which have the necessary creep strength on one side and the required resistance to corrosion / oxidation on the other side. It has hence become inescapable to bring coatings on to the surface of the blades to provide the necessary protection to the blades. The progress in coatings for gas turbine airfoils has been reviewed (Goward,1998). The function of the coating is to act as reservoir of elements which will form very protective and adherent oxide layers, thus protecting the underlying base material from oxidation, corrosion attack and degradation. Hot corrosion is distinctly different from the pure oxidation of an aircraft environment; it can therefore be readily appreciated that coatings for heavy duty gas turbines have different capabilities, compared to coatings for aircraft engines.

There are three basic types of coatings

- $\quad$ Aluminide (diffusion) coatings

- Overlay coatings

- Thermal barrier coatings (TBCs)

The diffusion coatings have been the most common type for environmental protection of superalloys. An outer aluminide layer $(\mathrm{CoAl}$ or $\mathrm{NiAl})$ with an enhanced oxidation resistance is developed by the reaction of $\mathrm{Al}$ with the $\mathrm{Ni} / \mathrm{Co}$ in the base metal. In recent years extremely thin layers of noble metals such as platinum have been used to enhance the oxidation resistance of aluminides. For most stage 1 buckets, GE used a platinum-aluminum diffusion coating until 1983 (Schilke, 2004). This coating offered superior corrosion resistance to straight aluminide coatings both in burner rig tests and in field trials. Their high temperature performance is however limited by oxidation behavior of the coatings.

GE has since switched over to overlay type coatings for stage 1 buckets (Schilke, 2004). At least one of the major constituents in a diffusion coating (generally $\mathrm{Ni}$ ) is supplied by the base metal. An overlay coating, in contrast, has all the constituents supplied by the coating itself. The advantage is that more varied corrosion resistant compositions can be applied to optimize the performance of the coating and thickness of the coating is not limited by process considerations. The coatings are generally referred to as MCrAlY, where M stands for $\mathrm{Ni}$ or $\mathrm{Co}$ or $\mathrm{Ni}+\mathrm{Co}$. Incorporation of yttrium improves corrosion resistance. The coatings are generally applied by vacuum plasma spray process. A high temperature heat treatment is performed $\left(1040-1120{ }^{\circ} \mathrm{C}\right)$ to homogenize the coating and ensure its adherence to the substrate. 
The TBCs provide enough insulation for superalloys to operate at temperatures as much as $150 \circ \mathrm{C}$ above their customary upper limit. TBCs are ceramics, based on $\mathrm{ZrO}_{2}-\mathrm{Y}_{2} \mathrm{O}_{3}$ and produced by plasma spraying.

The ceramic coatings use an underlay of a corrosion protective layer e.g., MCrAlY that provides the oxidation resistance and necessary roughness for top coat adherence. Failures occur by the thermal expansion mismatch between the ceramic \& metallic layers and by environmental attack on the bondcoat. This type of coating is used in combustion cans, transition pieces, nozzle guide vanes and also blade platforms. Improved efficiency of gas turbine engines is realized by adopting TBCs (Gurrappa \& Sambasiva Rao, 2006)

\subsection{R\&D efforts in progress in the area of coatings}

Development of even more corrosion resistant coating materials has been intensely pursued over the last few years. In particular, improvement of oxidation resistance and thermal fatigue resistance has been a focal theme for the R\&D efforts in the recent years. Development work is also on advanced TBCs to tailor their structure in such a way that they withstand thermal fatigue conditions better and give a longer life (Schilke, 2005). Development of techniques to ensure uniformity of applied coating has been another important area of research. High-velocity plasma appears to be getting established as the technique for application of overlay coatings. Much stronger bond between the coating and the workpiece and much higher coating densities can be achieved using this technique.

\section{Advanced materials under R\&D}

\subsection{Ceramics}

Increase in turbine inlet temperatures, beyond what is possible with superalloys, can be conceived if ceramic materials can be used in place of superalloys in gas turbine engine. Turbines would then operate at higher temperatures, yielding higher power with smaller engine sizes. Ceramic materials are known for their capability to withstand high temperatures. In addition they are quite tolerant to contaminants such as sodium and vanadium which are present in low cost fuels and highly corrosive to the currently used nickel-base superalloys. Ceramics are also up to $40 \%$ lighter than comparable high temperature alloys. They also cost much less - their cost is around 5\% the cost of superalloys. Ceramic materials based on silicon carbide and silicon nitride were identified in 1960's as potential candidates for gas turbine application. Substantial efforts have subsequently been conducted worldwide to identify and seek solutions for key challenges: improvement in properties of candidate materials, establishing a design and life prediction methodology, generating a material database, developing cost-effective fabrication of turbine components, dimensional and non-destructive inspection, and validation of the materials and designs in rig and engine testing. Enormous technical progress has been made, but ceramic-based turbine components still have not found application in gas turbine engines, because of the problem of brittleness (Richerson, 2006). There have been efforts to improve their ductility, e.g., through addition of aluminum to ceramics. Unless the problem of brittleness is overcome satisfactorily, the use of ceramics in gas turbines will not be practical.

\subsection{Intermetallics}

During the last 30 years, extensive efforts have gone into development of intermetallic alloys for application in aircraft gas turbine engines. The primary driving force was to replace 
nickel based alloys with a density of $8-8.5 \mathrm{gm} / \mathrm{cm}^{3}$ with lower density materials (4-7 $\mathrm{gm} / \mathrm{cm}^{3}$ ) and gain weight saving of the engine. Titanium and nickel based aluminides were the systems which received the maximum attention.

Excellent reviews are available on the subject of development of titanium based intermetallics for aero-engine applications (Gogia, 2005; Kumphert et al., 1998; Lasalmanie, 2006; Leyans \& Peters, 2003)

The titanium aluminum system offers two possibilities - the $\mathrm{Ti}_{3} \mathrm{Al}\left(\alpha_{2}\right)$ based intermetallics and the $\gamma$ TiAl based alloys. In the 1970's the research was centered mainly around the $\alpha_{2}$ alloys. Although interesting results were obtained, these materials did not get into flying engines because their fracture toughness and resistance to growth of fatigue cracks was significantly inferior to high temperature titanium alloys processed through conventional methods. They offered little or no advantage with reference to temperature capability over the alloys such as IMI 834, Ti6242, Ti1100. In their present state of development, there is not enough justification for wide spread usage of $\mathrm{Ti}_{3} \mathrm{Al}$ based intermetallics into aeroengines.

There is large volume of published work on second generation $\gamma$ TiAl alloys, developed in 1990 's. Considering the specific strength and oxidation resistance they are potential candidates to replace nickel alloys in the temperature range $650-750{ }^{\circ} \mathrm{C}$. These alloys have also interesting properties at lower temperatures - high Young's modulus and resistance to fire and good HCF properties. All the main turbine engine manufacturers including General Electric Aircraft Engines, Pratt and Whitney and Rolls Royce have successfully gone through demonstration programmes for rotating and static engine components in the compressor, combustor, turbine and nozzle.

Stronger third generation $\gamma$ TiAl alloys have been developed by GKSS with a wider temperature range of interest - room temperature to $850{ }^{\circ} \mathrm{C}$, making them candidate materials also for LP compressor components (Lasalmanie, 2006).

The most recent alloy family within the titanium aluminides is represented by the orthorhombic titanium based intermetallics based on $\mathrm{Ti}_{2} \mathrm{AlNb}$. They appear to have better toughness, higher ductility, higher specific strength and lower coefficient of thermal expansion than TiAl base intermetallics. This property profile makes orthorhombic titanium aluminides attractive for compressor casings. Even compressor discs can be considered, if their damage tolerance can be improved.

Table 13 is a compilation of representative grades from different groups of titanium aluminides and their maximum service temperature.

\begin{tabular}{|l|l|l|}
\hline $\begin{array}{l}\text { Group of titanium } \\
\text { aluminide }\end{array}$ & $\begin{array}{l}\text { Chemical composition of a typical } \\
\text { grade(s) }(\mathrm{At} \%)\end{array}$ & $\begin{array}{l}\text { Maximum service } \\
\text { temperature } \mathrm{oC}\end{array}$ \\
\hline $\mathrm{Ti}_{3} \mathrm{Al}$ based & $\begin{array}{l}\text { Ti-24Al-11Nb, Ti-25Al-10Nb-3V- } \\
\text { 1Mo }\end{array}$ & 550 \\
\hline $\begin{array}{l}\gamma \text {-TiAl based }\left(2^{\text {nd }}\right. \\
\text { generation) }\end{array}$ & Ti-48Al-2Cr-2Nb & 800 \\
\hline $\begin{array}{l}\gamma-\text { TiAl based (3rd } \\
\text { generation) }\end{array}$ & Ti-45Al-8Nb & 850 \\
\hline $\mathrm{Ti}_{2} \mathrm{AlNb}$ based & Ti-22Al-25Nb & 700 \\
\hline
\end{tabular}

Table 13. Representative grades of different groups of titanium aluminides

None of the potential applications talked above are expected to enter the production phase in the immediate future. There are serious hurdles, both technical and economic, on the 
way. The materials show large scatter in mechanical properties, with the result that the minimum property may be so low that the weight saving becomes negligible. They show very low tolerance to defects such as casting porosities, ceramic inclusions, machining cracks etc. There are a number of manufacturing difficulties. The production cost is much higher, compared to present technologies, particularly for complex components. Further research in alloy development and processing is required, it appears, before they get into flying aircraft engines.

$\beta \mathrm{NiAl}$ is better than current $\mathrm{Ni}$ alloys in high temperature oxidation and in creep at very high temperatures and was actively considered for turbine components in the range 1100$1650 \circ$ C. Serious obstacles to productionisation were faced - manufacturing difficulties, high cost of production, poor properties below $1000{ }^{\circ} \mathrm{C}$, intrinsic brittleness. Large amount of research was done to improve the mechanical properties by developing complex multiphase intermetallic structures. The manufacturing difficulties and the brittleness still plague these materials and they are unlikely to be adopted as gas turbine materials (Lasalmanie, 2006).

Many other intermetallic aluminide systems have been studied, to a lesser extent, in the context of application in aircraft engines; the materials have not taken off; the problems faced with their development are similar to those enumerated above.

\subsection{Composites}

\subsubsection{Polymer matrix composites}

Substantial progress has been made with reference to development and use of polymer matrix composites in the cold section of jet engines. GE is producing its front fan blades out of epoxy resin-carbon fiber composites, resulting in substantial weight savings.

\subsubsection{Titanium based metal matrix composites}

Continuous fibre reinforced titanium metal matrix composites have been the subject of intense R\&D activity, as they can lead to design changes from the conventional disc and dovetail arrangement to a bladed ring with a weight reduction of about $70 \%$. A number of processes are being evaluated for production of these composites. One of the major factors limiting the use of these composites is the fibre-matrix interaction leading to the degradation of properties. There have been many studies on the interaction between the fibre and the titanium based matrix. Different types of coatings have been tried to minimize this interaction. Titanium aluminides have received interest as matrix materials, because they show much less reaction with the fibres. Cutting down the cost of production, achieving improved performance levels and amenability to mass production are the key factors for the introduction of titanium based composites into gas turbine engines. Good overviews on the subject of titanium-based composite materials are available for the reader to get more information.(Gogia, 2005; Kumphert et al., 1998; Leyans \& Peters, 2003)

\subsubsection{Ceramic matrix composites (CMCs)}

The manufacturers of gas turbines are continually striving to increase the operating temperatures of their engines, leading to greater thermal efficiency, and reduced emission of harmful exhaust gases. These two drivers place an ever increasing burden on the materials used in, and the design of, hot gas path components. The introduction of CMCs into hot gas path components such as combustion chamber liners has long since been identified as a possible route to the achievement of increasing operating temperatures without incurring the penalties associated with increased cooling air use. 
SiC-matrix composites appear to be highly tailorable materials suitable to gas turbine application at high temperatures. Melt infiltrated (MI) $\mathrm{SiC} / \mathrm{SiC}$ composites are particularly attractive for gas turbine applications because of their high thermal conductivity, excellent thermal shock resistance, creep resistance, and oxidation resistance compared to other CMCs. They are tough, although their constituents are intrinsically brittle, when the fibermatrix bonding is properly optimized through the use of a thin interphase deposited on the fibers prior to the infiltration of the matrix. They display good mechanical properties at high temperatures when prepared from stable fibers, as well as a high thermal conductivity if their residual porosity is low enough. The matrix composition can also be tailored to improve the oxidation resistance of the composites.

Replacing the superalloys by light, tough, refractory and creep resistant SiC-matrix composites will permit a significant increase of service temperature and hence an increase of the engine efficiency, a reduction of the $\mathrm{NOx} / \mathrm{CO}$ emission (through an optimization of the fuel/air ratio), a simplification of the part design and a weight saving (typically, 30-50\%). However, their use still raises a number of questions dealing with their durability, reliability, manufacture, design and cost. Presently, the development of SiC-matrix composites is limited mostly to non rotating parts including combustor liners, after-burner components (exhaust cone and flame holder) and exhaust nozzles (outer and inner flaps) in military aerojet engines, as well as combustor liners of large size in stationary gas turbine for electrical power/steam cogeneration. The GE Rolls-Royce Fighter Engine Team's F136 development engine for the Joint Strike Fighter (JSF) contains third-stage, low-pressure turbine vanes made by GE from CMCs.

In summary, although substantial progress has been made, significant risks and challenges still remain before these composites can be commercialized for gas turbine components. The reader is referred to an overview on design, preparation and properties of non-oxide CMCs for application in gas turbine engines (Naslain, 2004)

\subsection{Chromium based alloys as gas turbine materials}

The increased efficiency associated with higher operating temperatures in gas turbines has prompted designers to search for new materials that can be used at temperatures above the useful limit of nickel-based superalloys. Chromium based alloys have been considered as a possible base for alloy systems due to their high melting point, good oxidation resistance, low density (20\% less than most nickel-based superalloys), and high thermal conductivity (two to four times higher than most superalloys). Considerable effort was made in the past, to explore the possibility of developing chromium-based alloys for high-temperature applications such as in jet engines. Two major disadvantages came in the way of their commercial exploitation. First, chromium alloys have a high ductile-to-brittle transition temperature. Second, chromium exhibits further embrittlement resulting from nitrogen contamination during high-temperature air exposure. Since the late 1970s, chromium alloys received very little attention. In recent years there is a revival of interest in these alloys $(\mathrm{Gu}$ et al., 2004). Aims of the recent researches have been (i) improvement in high temperature strength (ii) protection from nitridation / oxidation embrittlement (iii) improvement in the impact ductility at ambient temperature. There have been some encouraging findings - (i) trace additions of silver can improve room temperature ductility significantly (ii) strengthening with intermetallics can improve high temperature strength (iii) substantial progress has been made in the area of high temperature coatings (Gu et al.,2004). It is still a long way, however, before the engine manufacturers get interested in these alloys. 


\subsection{Molybdenum based alloys as gas turbine materials}

Molybdenum alloys are currently used as components for ultra-high-temperature applications under protective atmosphere, taking advantage of their high melting point and, very good mechanical and creep strength. However, they suffer from severe oxidation in air above around $500{ }^{\circ} \mathrm{C}$. Compositions based on Mo-9Si-8B have shown promise as structural materials for applications in excess of $1,100{ }^{\circ} \mathrm{C}$ in air (Heilmeier et al., 2009). The silicide and boride phases serve to provide oxidation resistance. Experiments to increase the oxidation resistance through alloying with $\mathrm{Cr}$ have shown promising results. Alloying with the reactive element $\mathrm{Zr}$ was also found to bring down the rate of oxidation. Creep resistance of the Mo-9Si-8B composition was found to be comparable or even superior to that of CMSX4 over the temperature range $1100-1200{ }^{\circ} \mathrm{C}$; there is scope for $\mathrm{R} \& \mathrm{D}$ to further increase the creep strength.

\subsection{Platinum based alloys}

Platinum-based alloys possess the potential to be used at temperatures up to $1,700{ }^{\circ} \mathrm{C}$. Despite their high prices, they are attractive for some gas turbine applications due to their exceptional resistance to oxidation, high melting points, ductility, thermal shock resistance, and thermal conductivity. They are envisaged to have potential for highly thermally loaded, but non-rotating parts in gas turbines (Alven, 2004). Work is in progress for development of platinum-based alloys with microstructures similar to those seen in commercial nickel-based alloys (Yamabe-Mitarai, 2004; Vorberg et al., 2004). Numerous research groups are currently involved in the study of these alloys. Significantly more data needs to be generated before the platinum-based alloys are ready for the designers of gas turbine engines.

\section{Conclusion}

Turbine entry temperature has increased by $\sim 500{ }^{\circ} \mathrm{C}$ over last 6 decades and about $150{ }^{\circ} \mathrm{C}$ of that is due to improved superalloys and introduction of DS / SC technologies for blade casting. Advanced thermal barrier ceramic coatings on platform and full airfoil have contributed to another about $100{ }^{\circ} \mathrm{C}$ of this improvement. The developments in gas turbine materials and coatings have been largely due to increasing demands placed by the aircraft sector - higher engine thrust, thrust to weight ratio and fuel efficiency - necessitating higher operating temperatures and pressures. The land based industrial gas turbine industry has placed its own demands on materials, bringing in resistance to hot corrosion as an important requirement. Several SC superalloy compositions have been developed for aircraft gas turbines on one side and land based gas turbines on the other side. Partial $\gamma^{\prime}$ solutioning has been adopted in a number of SC IGT alloys to avoid incipient melting and control the extent of recrystallisation. Intense $R \& D$ is also going on development of advanced materials for gas turbine engine application - intermetallics, ceramics, composites, chromium / molybdenum / platinum based materials to improve the engine efficiency and bring down the harmful emissions. Major improvements in the coating technology have also been achieved. Present day coatings last 10-20 times longer than the coatings used in the late 90 's. As much as $100 \%$ improvement is now being achieved in the blade life in the field through the process of coating. TBCs are being used in the first few stages in all advanced gas turbines. Intense R\&D is underway to improve the thermal fatigue of the TBC's and thereby increase their life. This includes development of techniques for production of uniform and high density coatings. 


\section{Acknowledgment}

The author is grateful to the Management of VIT University for their kind consent to publish this Chapter. He is also indebted to Ms. Brunda, his wife, for all the support he received from her in preparing this manuscript.

\section{References}

Alven, D.A. Refractory- and Precious Metal- Based Superalloys, JOM, Vol.56, No.9, pp 27 ISSN 1047-4838

Bayer, R.R. An Overview on the Use of Titanium in the Aerospace Industry, Materials Science and Engineering A, Vol.A213, (1996), pp103-114 ISSN 0921-5093

Boyce, M.P. (2006). Gas Turbine Engineering Handbook, (Third Edition), Gulf Professional Publishing, ISBN 0-88415-732-6, OxfordCaron, P.; Green, K.A. \& Reed, R.C. (Eds.). (2008) Superalloys: Proceedings of the Eleventh International Symposium on Superalloys , TMS, ISBN 0873397282, Warrendale, PA

Coutsouradis, D.; Davin, A. \& Lamberigts, M.(1987) Cobalt-based Superalloys for Application in Gas Turbines, Materials Science and Engineering, Vol.88, pp11-19, ISSN 0921-5093

Das, N. (2010). Advances in Nickel-base Cast Superalloys, Transactions of The Indian Institute of Metals, Vol.63, No.2-3, (April-June 2010), pp265-274, ISSN 0972-2615

Davis, J.R. (Ed.). (1997). Heat Resistant Materials, ASM Speciality Handbook, ASM International, ISBN 978-0-87170-596-9, Materials Park, OH

Davis, J.R. (2000). Nickel, Cobalt and their Alloys, ASM Speciality Handbook, ASM International, ISBN 0-87170-685-7, Materials Park, OH

DeHaemer, M.J. (1990). ASM Handbook, Volume 1, Properties and Selection: Irons, Steels, and High Performance Alloys, Wrought and Powder Metallurgy (P/M) Superalloys, ASM International, ISBN 0-87170-377-7, Materials Park, OH

Donachie, M.J. (August 2000). Titanium, A Technical Guide, 2 Edition, ASM International, ISBN 0871706865, USA

Donachie, M.J.; \& Donachie, S.J. (2002). Superalloys A Technical Guide, (Second Edition), ASM International, ISBN 978-0-87170-749-9, The Materials Society, Materials Park, Ohio

Durand-Charre, M. (1998). The Microstructure of Superalloys, CRC Press, ISBN 9056990977

Eliaz, N.; Shemesh, G. \& Latanision, R.M. (2002). Hot Corrosion in Gas Turbine Components. Engineering Failure Analysis, Vol.9, pp.31-43, ISSN 1350-6307

Furrer, D. \& Fecht, H. (1999). Ni-Based Superalloys for Turbine Discs. JOM, Vol.51, No.1, (January 1999), pp. 14-17, ISSN 1047-4838

Gibbons, T.B. Superalloys in Modern Power Generation Application, Materials Science and Technology, Vol.25, No.2, pp129-135

Gogia, A.K. (2005). High Temperature Titanium Alloys, Defence Science Journal, Vol.55, No.2, (April 2005), pp149-173, ISSN 0011748X

Goward, G.W. (1998). Progress in coatings for gas turbine airfoils. Surface and Coatings Technology, Vol.108-109, pp. 73-79, ISSN 0257-8972 
Gu, Y.F.; Harada, H. \& Ro,Y. (2004). Chromium and Chromium-Based Alloys: Problems and Possibilities for High Temperature Service. JOM, Vol.56, No.9 (September 2004), pp. 28-33, ISSN 1047-4838

Gurrappa, I. \& Sambasiva Rao, A. (2006). Thermal Barrier Coatings for Enhanced Efficiency of Gas Turbine Engines, Surface \& Coatings Technology, Vol.201, (2006), pp30163029 ISSN 0257-8972

Heilmeier, M.; Krüger, M.; Saage, H. \& Rösler, J. Metallic Materials for Structural Applications Beyond Nickel-based Superalloys JOM, Vol.61, No.7, pp61-67 ISSN $1047-4838$

Kumphert, J.; Peters, M. \& Keysser, W.A. The Potential of Advanced Materials on Structural design of Future Aircraft engines, Proceedings of RTO AVT Symposium on “ Design, Principles and Methods for Aircraft gas Turbine engines", ISBN 92-8370005-8, Toulouse, France, May 11-15, 1998

Lasalmanie, A. (2006). Intermetallics: Why is it so Difficult to Introduce them in Gas Turbine Engines?, In: Intermetalics, Vol.14, No.10-11, (October 2006), pp1123-1129, ISSN 0966-9795

Leyans, C \& Peters, M. (2003). Titanium and Titanium Alloys: Fundamentals and Applications, Wiley-VCH Verlag GmbH \& Co, ISBN 9783527305346, Weinheim, FRG

Loria, E.D. (1989). Proceedings of Conference on Superalloy 718 - Metallurgy and Applications, TMS, ISBN 0-87339-097-0, Warrendale, PA

Loria, E.D. (1991). Proceedings of Conference on Superalloy 718, 625 and various Derivatives, TMS, ISBN 0-87339-173X, Warrendale, PA

Loria, E.D. (1994). Superalloys 718, 625, and Various Derivatives, The Minerals, Metals \& Materials Society, ISBN 0-87339-235-3, Warrendale, PA

Loria, E.D. (1997). Superalloys 718, 625, 706 and Various Derivatives, The Minerals, Metals \& Materials Society, ISBN 0-87339-376-7, Warrendale, PA

Loria, E.D. (2001). Proceedings of the Fifth International Conference on Superalloys 718, 625, 706 and Various Derivatives, TMS, ISBN 0-87339-510-7, Warrendale, PA

Loria, E.D. (2005). Proceedings of Sixth International Symposium on Superalloys 718, 625, 706 and Derivatives, TMS, ISBN 978-0-87339-602-8, Warrendale, PA

Naslain, R. (2004) Design, preparation and properties of non-oxide CMCs for application in engines and nuclear reactors: an overview. Composites Science and Technology, Vol.64, pp155-170, ISSN 0266-3538

Reed, R.C. (2006). Superalloys: Fundamentals and Applications, Cambridge University Press, ISBN 9780521859042

Richerson, D.W. (2006). Historical review of addressing the challenges of use of ceramic components in gas turbines, Proceedings of 2006 ASME 51 st Turbo Expo, ISBN 0791842371, Barcelona, May 2006

Schilke, P.W. (2004) Advanced Gas Turbine Materials and Coatings, 18.04.2011, Available from www.gepower,com/prod_serv/products/tech_docs/en/downloads/ger3569g.pdf

Vorberg, S.; Wenderoth, M.; Fischer, B.; Glatzel, U. \& Völkl, R. Pt-Al-Cr-Ni Superalloys: Heat Treatment and Microstructure, JOM, Vol.56, No.9, pp40-43 ISSN 1047-4838 
Wright, I.G. \& Gibbons, T.B.(2007) Recent developments in gas turbine materials and technology and their implications for syngas firing. International Journal of Hydrogen Energy, Vol.32, pp 3610-3621, ISSN 0360-3199

Yamabe-Mittarai, Y. (2004). Platinum-Group-Metals-Based Intermetallics as HighTemperature Structural Materials, JOM, Vol.56, No.9, pp ISSN 1047-4838 


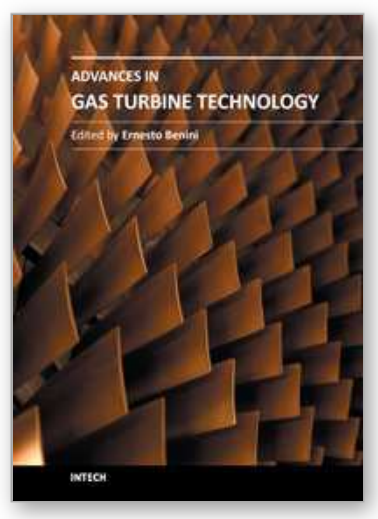

\author{
Advances in Gas Turbine Technology \\ Edited by Dr. Ernesto Benini
}

ISBN 978-953-307-611-9

Hard cover, 526 pages

Publisher InTech

Published online 04, November, 2011

Published in print edition November, 2011

Gas turbine engines will still represent a key technology in the next 20-year energy scenarios, either in standalone applications or in combination with other power generation equipment. This book intends in fact to provide an updated picture as well as a perspective vision of some of the major improvements that characterize the gas turbine technology in different applications, from marine and aircraft propulsion to industrial and stationary power generation. Therefore, the target audience for it involves design, analyst, materials and maintenance engineers. Also manufacturers, researchers and scientists will benefit from the timely and accurate information provided in this volume. The book is organized into five main sections including 21 chapters overall: (I) Aero and Marine Gas Turbines, (II) Gas Turbine Systems, (III) Heat Transfer, (IV) Combustion and (V) Materials and Fabrication.

\title{
How to reference
}

In order to correctly reference this scholarly work, feel free to copy and paste the following:

Nageswara Rao Muktinutalapati (2011). Materials for Gas Turbines - An Overview, Advances in Gas Turbine Technology, Dr. Ernesto Benini (Ed.), ISBN: 978-953-307-611-9, InTech, Available from: http://www.intechopen.com/books/advances-in-gas-turbine-technology/materials-for-gas-turbines-an-overview

\section{INTECH}

open science | open minds

\section{InTech Europe}

University Campus STeP Ri

Slavka Krautzeka 83/A

51000 Rijeka, Croatia

Phone: +385 (51) 770447

Fax: +385 (51) 686166

www.intechopen.com

\section{InTech China}

Unit 405, Office Block, Hotel Equatorial Shanghai

No.65, Yan An Road (West), Shanghai, 200040, China

中国上海市延安西路65号上海国际贵都大饭店办公楼405单元

Phone: +86-21-62489820

Fax: +86-21-62489821 
(C) 2011 The Author(s). Licensee IntechOpen. This is an open access article distributed under the terms of the Creative Commons Attribution 3.0 License, which permits unrestricted use, distribution, and reproduction in any medium, provided the original work is properly cited. 